\title{
High-temperature grain drying: an economic analysis applied to Brazilian conditions
}

\begin{abstract}
Grain drying is one of the most important steps of postharvest handling. Among the artificial drying methods, the high-temperature drying is the fastest, less energy consuming and less dependent on local climate, but also more expensive. A detailed methodology for economic analysis of high-temperature grain drying, involving the main variables that affect its profitability, is presented and tested. The proposed methodology is based on the cash flow model and was tested considering Brazilian market conditions, comprising 42 simulated scenarios. The performed economic analysis can be easily adapted to other grains, countries, furnace fuels, and drying capacities as well. Results showed that all of the simulated scenarios were economically feasible provided that at least five drying cycles are performed per year. Labor, social taxes, grain type and drying capacity most affected the economic feasibility of this kind of investment, while the furnace fuel did not influence the evaluated economic indices.
\end{abstract}

Volume 4 Issue I - 2020

\section{Pricila Araújo Santana, Daniela de Carvalho Lopes, Antonio José Steidle Neto}

Department of Agrarian Sciences, Federal University of São João del Rei, Brazil

\author{
Correspondence: Antonio José Steidle Neto, Federal \\ University of São João del-Rei, MG 424, km 47, Sete Lagoas, \\ Minas Gerais, Brazil, Tel +55 (31) 3775-552I, \\ Email antoni@ufsj.edu.br
}

Received: January 29, 2020 | Published: February 27, 2020

Keywords: dryer, economic feasibility, modelling, postharvest, storage

Abbreviations: NPV, net present value; BCR, benefit-cost ratio; IRR, internal rate of return; $P P$, payback period

\section{Introduction}

Grain drying is one of the most important steps of postharvest handling, appearing as the main preservation method due to its proven flexibility, technology and reliability. ${ }^{1}$ This process is employed with the main objective of reducing the grain water content to appropriate preservation levels, comprising simultaneous heat and mass transfers between drying air and grain, in such way that the product reaches an equilibrium condition considered suitable for preserving its physical, physiological and nutritious features., ${ }^{2,3}$ Among the artificial drying methods, the high-temperature drying appears as the fastest, less energy consuming and less dependent on local climate., 4 Although not commonly used in less developed regions due to its high initial investment, this drying technique is desirable in many industrial processes, such as in wet rice drying since it can be beneficial to the cooking quality of this product, as well as in feed industry because high temperatures tend to enhance corn starch digestibility. ${ }^{6}$

High-temperature dryers can be classified according to their operation (continuous or batch) and design (fixed bed, fluidized bed, rotating, cross-flow, concurrent-flow, mixed-flow or counter-flow). However, mixed flow column dryers are the most popular because they contribute to a better drying uniformity across the grain column since the entire width is subjected to the same air and the grain is mixed as it passes through the drier. Further, compared with the other dryers, they do not occupy grain storage space, allow drying of small grain without losses, can be built with portable units and moved easily, as well as can be simply cleaned between crops. ${ }^{7}$

In addition to the dryer design, drying capacity and stored grain, the furnace fuel is important to ensure an efficient process. Wood is a very popular fuel for grain drying, due to its low cost and high availability when compared to other fuels. However, its use presents disadvantages such as discontinuous and irregular combustion, formation of soot and toxic substances, as well as the demand for large forest plantations. ${ }^{8}$ On the other hand, the use of biomass (straw, husk, cob, bagasse and forest residues) has been increasing due to its potential for renewable energy generation and low carbon emissions. ${ }^{9}$ Replacing coal and natural gas with agricultural residues can reduce around $93 \%$ and $85 \%$ of net $\mathrm{CO}_{2}$ emissions, respectively. ${ }^{10}$ Other advantages of using agricultural residues as furnace fuels are the large amount and availability for immediate use. ${ }^{11}$

Just as important as the technical factors is the drying economic feasibility, which can be evaluated by an economic analysis performed with the main objectives of verifying all the project risks and minimizing investment failures. ${ }^{12,13}$ One of the tools used for performing this analysis is the cash flow model, representing a balance of the amount of revenues and expenses of an investment during the lifetime of the project, and indicating its feasibility by economic indices. ${ }^{14}$ Several authors already evaluated the economic feasibility of grain drying by simulations, but they considered products, dryers and, bulk volumes in isolation, as well as short project lifetimes. ${ }^{13,15-17}$ There is a need for a joint analysis involving the main technical and economic parameters of this process, also considering the effects of different grain types, furnace fuels and bulk volumes on the hightemperature drying expenses and revenues. This work presents a detailed methodology for economic analysis of high-temperature grain drying, based on the cash flow model, which allows the evaluation of revenues and expenses, as well as the impacts of the main system variables, on the economic feasibility of high-temperature drying. The proposed methodology was tested considering different Brazilian storage conditions.

\section{Material and methods}

\section{Economics of high-temperature grain drying}

The cash flow model was applied to estimate the economic returns of high-temperature drying systems considering a project lifetime of 20 years. This period was based on the average useful life of grain 
dryers and other equipment used in the process. ${ }^{18}$ The cash flow represents the saved amount of money resulting from the difference between revenues and expenses of grain drying during the lifetime of the project. The year zero considers no revenues and the capital investment as expenses. For the other years, revenues and expenses are calculated as:

$$
\begin{gathered}
R_{i}=\left(\begin{array}{ll}
C \text { G G }
\end{array}\right)(1+j)^{i} \\
E_{i}=D_{i}+M_{i}+Q_{i}+L_{i}+T_{i}+E_{i}+F_{i}
\end{gathered}
$$

Where: $\mathrm{R}=$ revenues in $\$$, $\mathrm{i}=$ year considered in the cash flow, varying from 1 to the lifetime of the project, $\mathrm{C}=$ the number of drying cycles, $\mathrm{Ga}=$ amount of dried grain in $\mathrm{kg}, \mathrm{Gp}=$ selling price of grain in $\$, j=$ annual inflation rate in decimal, $\mathrm{D}=$ depreciation cost in $\$$, $\mathrm{M}=$ maintenance costs in $\$, \mathrm{Q}=\mathrm{dry}$ matter loss costs in $\$, \mathrm{~L}=$ labor costs in $\$, T=F e d e r a l$ tax costs in $\$, E=$ electrical energy costs in $\$$ and $F=$ fuel costs in $\$$.

The number of drying cycles was added to the analysis in order to identify the minimal value required to guarantee economic feasibility for the studied condition. More drying cycles tend to improve the profitability of the grain drying. Straight-line depreciation was used to gradually allocate depreciation of the drying systems along the lifetime of the project with a $10 \%$ discount rate: ${ }^{19}$

$$
D_{i}=D_{i-1}+(V 0-0.1 V 0) / N
$$

Where $\mathrm{V} 0=$ capital investment in $\$$ and $\mathrm{N}$ is the project lifetime. The year zero considers no depreciation, that is D0 is zero. Maintenance costs represented the annual expenses with repair and part replacement, considering the inflation rate. It was calculated as $3 \%$ of the capital invested on the drying system: ${ }^{13}$

$$
M_{i}=(0.03 V 0)(1+j)^{i}
$$

Dry matter losses of $0.5 \%$ due to transportation and drying were used, indicating high grain quality, but at the same time affecting the total volume of commercialized grain: ${ }^{20}$

$$
Q_{i}=(0.005 C G a G p)(1+j)^{i}
$$

Labor costs mainly depended on the wage value, the number of employees, their workload and the social taxes, also considering the inflation rate:

$$
L_{i}=(N e C L w W(1+S t / 100))(1+j)^{i}
$$

Where $\mathrm{Ne}=$ number of employees, $\mathrm{Lw}=$ employee annual workload in $\mathrm{h}, \mathrm{W}=$ wage cost in $\$$, and $\mathrm{St}=$ social taxes in $\%$ of wage.

Other taxes and fees related to the high-temperature drying process corresponded to a percentage of the capital invested in the system, discounting the inflation rate:

$$
T_{i}=(V 0 T r)(1+j)^{i}
$$

Where $\mathrm{Tr}=$ taxes index in \% capital investment.

Electrical energy and fuel costs were calculated based on the dryer consumption and the drying time:

$$
\begin{aligned}
& E_{i}=(C K c D t C k)(1+j)^{i} \\
& F_{i}=(C F a C f+F c)(1+j)^{i}
\end{aligned}
$$

Where $\mathrm{Kc}=$ cost of electrical energy in $\$ \mathrm{kWh}^{-1}, \mathrm{Dt}=$ drying time in $\mathrm{h}, \mathrm{Ck}=$ electrical consumption in $\mathrm{kW}, \mathrm{Fa}=$ amount of fuel required for drying in $\mathrm{kg}, \mathrm{Cf}=$ cost of fuel in $\$ \mathrm{~kg}^{-1}$, and $\mathrm{Fc}=$ freight cost in $\$$. With the cashflow data, the economic indices Net Present Value (NPV), BenefitCost Ratio (BCR), Internal Rate of Return (IRR) and Payback Period (PP) were calculated in order to evaluate the economic feasibility of high-temperature grain drying. NPV (Eq. 10) is frequently used when making financial decisions, representing the value today of a future earning with high-temperature drying, discounting the inflation rate..$^{21}$ The investment will be profitable only if NPV is greater than zero. ${ }^{14}$

$$
\mathrm{NPV}=\mathrm{V}_{0}+\sum_{\mathrm{i}=1}^{\mathrm{N}}\left[\left(\mathrm{F}_{\mathrm{L}}\right)_{\mathrm{i}}\left(1+\frac{\mathrm{j}}{100}\right)^{-\mathrm{i}}\right]
$$

Where $\mathrm{F}_{\mathrm{L}}=$ cash flow in $\$$.

$\mathrm{BCR}$ is a reliable accounting method to demonstrate savings from high-temperature drying systems, calculated as the quotient between the benefits and costs of the project, discounting the inflation rate (Eq. 11). High-temperature drying systems will be economically feasible only if BCR is greater than one. ${ }^{22}$

$$
B C R=(N P V-|V 0|) /|V 0|
$$

PP refers to the smallest number of years in which the hightemperature drying recovers its investments by the cumulative revenues. This index was calculated iteratively by applying Eq. 12 for each year of the project lifetime until a value greater than the initial investment was found. ${ }^{21}$ Thus, PP was associated with the last year considered at the end of iterations and the drying system was profitable if this index was smaller than the project lifetime.

$$
(V p)_{i}=(V p)_{i-1}+(F L)_{i} /(1+j / 100)^{i}
$$

Where $\mathrm{Vp}=$ annual recovered value in $\$$.

The IRR equates the NPV to zero, providing valuable information about the return on high-temperature drying systems. In this study IRR was calculated iteratively by inverse Lagrange interpolation. ${ }^{21}$ Worthwhile drying systems have IRR greater than the attractiveness rate, considered as the minimum acceptable return percentage that this kind of project must earn in order to be profitable.

\section{Testing the cash flow model applied to high temperature grain drying}

Brazilian high-temperature drying systems were considered during the tests, due to the large grain production verified in this country, and taking account that the grains play an important role in the Brazilian agricultural scenario as commodities, both for internal consumption and exportation.

Three high-temperature dryer volumes $\left(83.9 \mathrm{~m}^{3} ; 104.9 \mathrm{~m}^{3} \mathrm{e}\right.$ $227.1 \mathrm{~m}^{3}$ ) were simulated considering the most common designs found in Brazil. ${ }^{23-25}$ These were mixed-flow column dryers with double air recirculation system, which demand less electrical energy, resulting in higher thermal efficiency and in better drying uniformity. Additionally, two furnace fuels (wood and grain residues) and seven grain types (peanut, rice, coffee, bean, corn, soybean and wheat) were used, based on their market importance in Brazil, totaling 42 simulation scenarios. ${ }^{26}$

High-temperature drying times and electrical energy consumptions were simulated based on the average technical features of the dryers 
(Table 1), as well as on common grain and air conditions. In this study it was considered the grain drying from 20 to $13 \%$ (w.b). Further, the air heating from 20 to $110^{\circ} \mathrm{C}$ was applied, following the specified by the dryer manufacturers (Table 1). ${ }^{23-25}$

Table I Technical features of dryers considering soybean drying and water content reduction from wet-basis 18 to $13 \%$

\begin{tabular}{llll}
\hline & $\begin{array}{l}\text { Small } \\
\text { dryer }\end{array}$ & $\begin{array}{l}\text { Middle } \\
\text { dryer }\end{array}$ & $\begin{array}{l}\text { Large } \\
\text { dryer }\end{array}$ \\
\hline Static capacity $\left(\mathrm{m}^{3}\right)$ & 83.9 & 104.9 & 227.1 \\
Nominal capacity $\left(\mathrm{t} \mathrm{h}^{-1}\right)$ & 40 & 60 & 125 \\
Airflow $\left(\mathrm{m}^{3} \mathrm{~h}^{-1}\right)$ & 72,000 & $1,08,000$ & $2,25,000$ \\
Required heat $\left(\mathrm{kcal} \mathrm{h}^{-1}\right)$ & $18,00,000$ & $27,00,000$ & $56,25,000$ \\
Required power $(\mathrm{cv})$ & 25 & 40 & 75 \\
\hline
\end{tabular}

Time of each drying cycle was estimated by dividing the grain volume by an effective drying capacity, adjusted according to the nominal capacity of the dryer, grain type and grain moisture contents before and after the drying process (Eq. 13). The correction factor for product type was estimated since original technical features of dryers refer to soybean. This correction factor was calculated based on the nominal capacity of the dryer and the different grain bulk densities, resulting in the values of $1.113,0.968,1.160,0.740,0.746,1.000$ and 0.683 for peanut, rice, coffee, bean, soybean and wheat, respectively. The correction factor for grain water content (Eq. 14) was calculated following recommendations of Valente et al., ${ }^{12}$ considering that dryers were designed to reduce the grain water content from 18 to $13 \%$ (w.b.).

$$
C e=C n f p f u
$$

$F u=1-0.1544(U i-18)+0.014863(U i-18)^{2}-0.0005942(U i-18)^{3}(14)$

Where $\mathrm{Ce}=$ effective drying capacity in $\mathrm{t}^{-1}, \mathrm{Cn}=$ nominal drying capacity for soybean in $\mathrm{t} \mathrm{h}^{-1}, \mathrm{fp}=$ correction factor for product in decimal, $\mathrm{fu}=$ correction factor for water content in decimal, and $\mathrm{Ui}=$ initial grain water content in $\% \mathrm{wb}$.

Energy consumption was estimated by multiplying the required power of the dryer by 0.7355 and by the drying time, resulting in the consumption in $\mathrm{kWh}$. The amount of fuel was calculated considering a furnace efficiency of $80 \% .{ }^{27}$

$$
M c=60 \rho Q c p(T s-T a) /(\eta P C I)
$$

Where $\mathrm{Mc}=$ fuel consumption in $\mathrm{kg} \mathrm{h}^{-1}, \rho=$ drying air density in $\mathrm{kg}$ $\mathrm{m}^{-3}, \mathrm{Q}=$ drying airflow rate in $\mathrm{m}^{3} \mathrm{~min}^{-1}, \mathrm{Cp}=$ specific heat of drying air in $\mathrm{kJ} \mathrm{kg}^{-1}{ }^{\circ} \mathrm{C}^{-1}, \mathrm{Ta}=$ ambient air temperature in ${ }^{\circ} \mathrm{C}, \mathrm{Ts}=$ drying air temperature in ${ }^{\circ} \mathrm{C}, \eta=$ furnace efficiency in decimal, and $\mathrm{PCI}=$ low calorific value of fuel in $\mathrm{kJ} \mathrm{kg}^{-1}$.

Table 2 presents the yields, collecting availability factors and low calorific values of the grain residues used in this study. ${ }^{27,28,29}$ Yields and collecting availabilities were evaluated to compare the amount of biomass required as furnace fuel with values generally used for adequate soil fertilization and protection, animal feed and other agricultural practices. The low calorific value of wood was simulated as $12,970 \mathrm{~kJ} \mathrm{~kg}^{-1}$ (Table 2). ${ }^{28}$
Table 2 Yields, availability factors and low calorific values of the studied grain

\begin{tabular}{|c|c|c|c|}
\hline Residue & $\begin{array}{l}\text { Yield } \\
(\text { tdb/t })^{*}\end{array}$ & $\begin{array}{l}\text { Collecting } \\
\text { availability (\%) }\end{array}$ & $\begin{array}{l}\text { Low calorific } \\
\text { value }(\mathbf{k J} / \mathbf{k g})\end{array}$ \\
\hline Soybean straw & 2.3 & 30 & 14,600 \\
\hline Corn straw & 1.68 & 40 & 17,700 \\
\hline Rice straw & 1.55 & 40 & 16,000 \\
\hline Rice husk & 0.19 & 40 & 16,000 \\
\hline Wheat straw & 2.9 & 40 & 12,400 \\
\hline Bean straw & 1.16 & 40 & 14,000 \\
\hline Coffee husk & 2 & 50 & 15,500 \\
\hline Peanut husk & 1.04 & 25 & 12,900 \\
\hline
\end{tabular}
residues

*tdb expresses tons of residues in dry basis and $\mathrm{t}$ expresses tons of grain

The average capital investments of high-temperature systems, including furnace and dryer costs, were obtained from Brazilian manufacturers, corresponding to $\$ 79,792.09,98,020.79$ and 171,585.36 for small, middle and large dryers, respectively. ${ }^{23-25}$ Table 3 shows the bulk volumes, which varied for equal dryer sizes due to their different densities, as well as average selling prices (obtained by agribusiness websites), which were different depending on the grain type (Table 3).

Table 3 Average selling prices of grain used in simulations and bulk volumes depending on the dryer size

\begin{tabular}{lllll}
\hline \multicolumn{5}{c}{ Grain bulk volume (ton) } \\
\hline Grain & $\begin{array}{l}\text { Selling } \\
\text { price } \\
\left(\$ \text { ton }^{-1}\right)\end{array}$ & $\begin{array}{l}\text { Small } \\
\text { dryer }\end{array}$ & $\begin{array}{l}\text { Middle } \\
\text { dryer }\end{array}$ & $\begin{array}{l}\text { Large } \\
\text { dryer }\end{array}$ \\
\hline Peanut & $464.9 \mathrm{~m}^{3}$ & $104.9 \mathrm{~m}^{3}$ & $227.1 \mathrm{~m}^{3}$ \\
Rice & 212.71 & 42.87 & 53.6 & 116.05 \\
Coffee & $2,049.72$ & 41.95 & 52.45 & 113.55 \\
Bean & 690.71 & 62.93 & 78.68 & 170.33 \\
Corn & 127.07 & 62.93 & 78.68 & 170.33 \\
Soybean & 295.58 & 52.86 & 66.09 & 143.07 \\
Wheat & 174.03 & 67.54 & 84.44 & 182.82 \\
\hline
\end{tabular}

The simulated annual inflation rate was $10 \%$ and represented the percentage increase in the prices over a year. ${ }^{22,30}$ Costs of electrical energy $\left(\$ 0.11 \mathrm{kWh}^{-1}\right)$ were based on the current fees in Brazil. ${ }^{31,32,33}$ Labor costs were simulated as $\mathrm{R} \$ 22.10$ per employee per day and social taxes were $68 \%$ of the payroll. ${ }^{34}$ Other taxes and fees related to the low-temperature drying process corresponded to $10 \%$ of the capital invested in the system. ${ }^{26}$ Further, an attractiveness rate of $7 \%$ was employed, representing a perceived quality and utility of grain 
drying systems and contributing to the evaluation of their economic feasibility. ${ }^{13,14}$ An average wood cost of $\$ 0.04$ was used based on data from agribusiness websites, while grain residues were considered costless since they are recycled from the cultivation area. Further, during the studied period, the real (R\$) to US dollar conversion was $\$ 3.62 .{ }^{30}$

After all economic analyses were performed by using the proposed model, the simulated scenarios were compared among themselves and the main factors that affected their economic feasibility were evaluated. All calculations and analyses were accomplished by using electronic worksheets.

\section{Results}

All of the 42 simulated scenarios were profitable when performing at least five drying cycles per year. VPLs ranged approximately from \$276 thousand to \$22 million at the end of the 20 years considered as project lifetime (Figure 1).

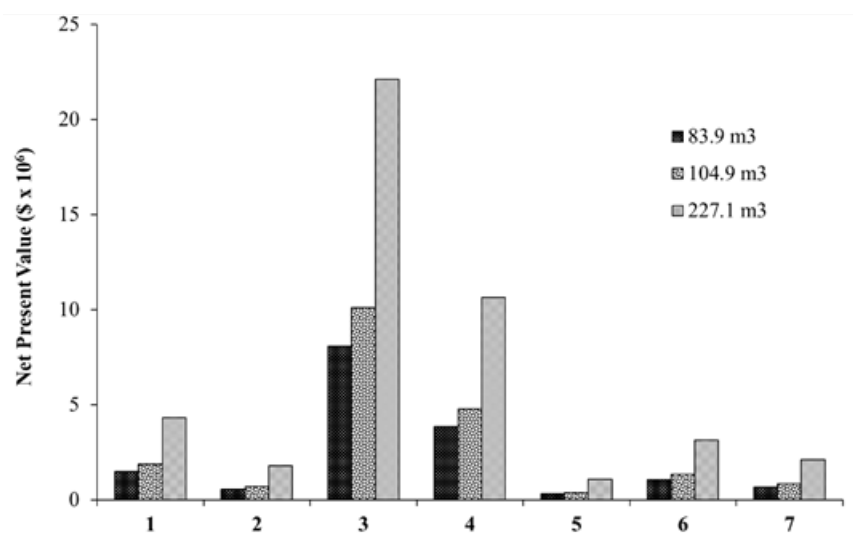

Figure I Average Net Present Values (NPV) of the simulated scenarios considering small $\left(83.9 \mathrm{~m}^{3}\right)$, middle $\left(104.9 \mathrm{~m}^{3}\right)$ and large $\left(227.1 \mathrm{~m}^{3}\right)$ volume dryers.

Figure 2 shows the average BCRs for different grain types and dryer capacities, which ranged from 2.8 to 127.9 .

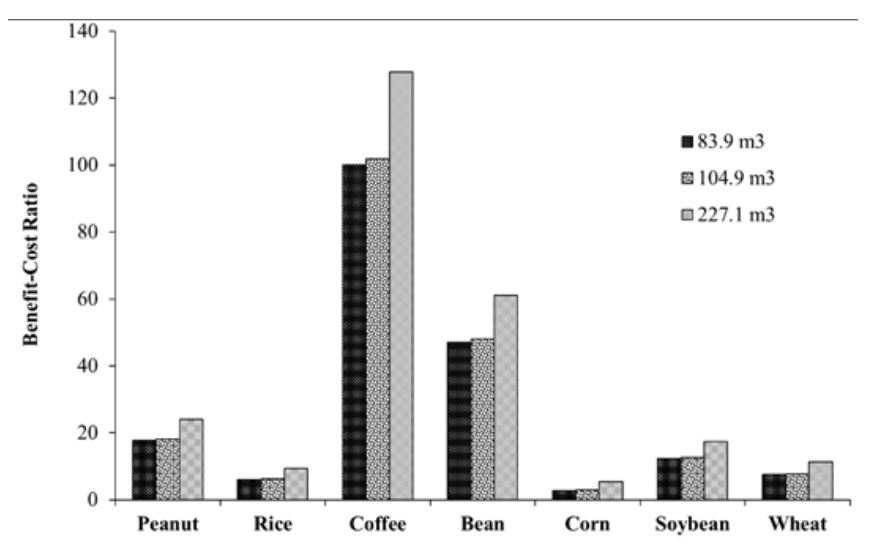

Figure 2 Average Benefit-Cost Ratios (BCR) of the simulated scenarios considering small $\left(83.9 \mathrm{~m}^{3}\right)$, middle $\left(104.9 \mathrm{~m}^{3}\right)$ and large $\left(227.1 \mathrm{~m}^{3}\right)$ volume dryers.

As shown in Figure 3, IRRs were between 27.2 and 100.0\%, with high value grain and large dryers resulting in greater returns. Among the 42 simulated high-temperature drying processes, 20 resulted in immediate PPs, with emphasis on drying small, middle and large volumes of coffee, bean and peanut. In all other scenarios PPs varied from 1.5 years when drying wheat to 3.5 years for corn drying. Other variables which were important during the economic analysis were the electrical energy consumption, drying time and amount of fuel required for drying. Their values varied according to the grain and fuel types, as well as dryer capacity. The average electrical energy consumptions were $18.39,29.42$ and $55.16 \mathrm{~kW}$ for small, middle and large high-temperature drying systems, respectively. On the other hand, the average drying times were most affected by grain type, with averages of 1.1 1.5, 1.1, 2.6, 2.6, 1.6 and 3.0 hours for peanut, rice, coffee, corn, soybean and wheat, respectively. The amounts of fuel for each simulated scenario are presented in Table 4.

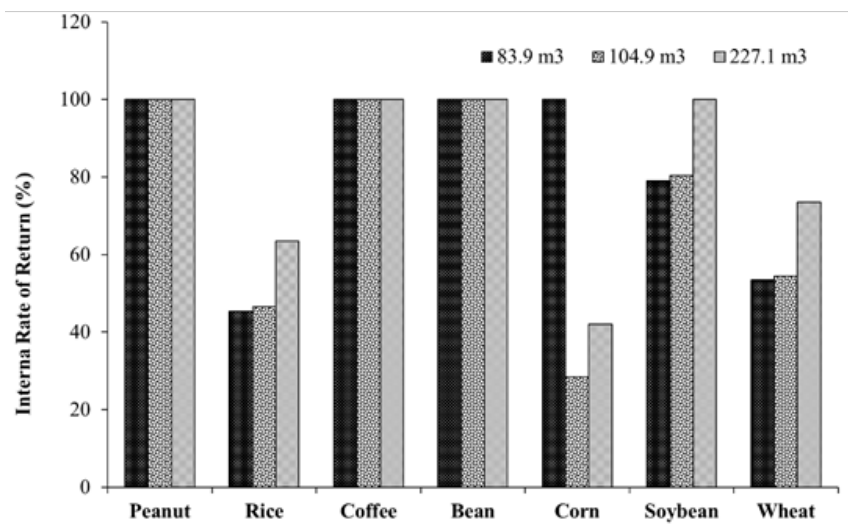

Figure 3 Average Internal Return Ratios (IRR) of the simulated scenarios considering small $\left(83.9 \mathrm{~m}^{3}\right)$, middle $\left(104.9 \mathrm{~m}^{3}\right)$ and large $\left(227.1 \mathrm{~m}^{3}\right)$ volume dryers.

Table 4 Biomass and wood amounts $(\mathrm{kg})$ required as furnace fuel for different high-temperature drying systems in Brazil

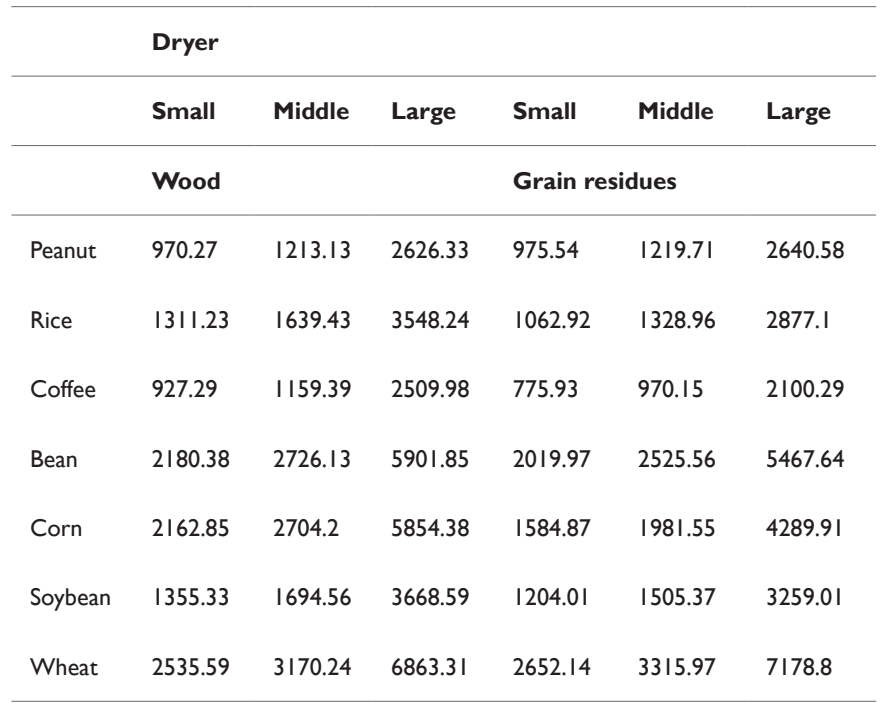

\section{Discussion}

The proposed model has been found reliable and satisfactory. The costs and revenues simulated in this study agreed well with the market and literature data, with monetary corrections. ${ }^{12,13,15,17,35}$ The smallest NPVs were observed when drying corn, rice and wheat in small and middle high-temperature dryers, while the greatest returns were verified for drying of large volumes of coffee and bean. Major 
contributors for these results were selling prices of grain and dried bulk volumes. This is well demonstrated in the particular case of rice and wheat, which resulted in average NPVs of $\$ 1.02$ and 1.21 million, respectively. Selling prices of these products are greater than corn and smaller than the other grain types, but rice is around $18.2 \%$ more expensive than wheat. However, considering a same dryer capacity it is possible to dry a volume of wheat approximately $26.6 \%$ greater than rice due to their bulk densities. Generally, large dryers were responsible for greater NPVs for a same grain type and high cost grains resulted in greater revenues along the lifetime of the project.

Smallest values of BCR index were also found for corn, rice and wheat drying, demonstrating a lower profitability for these investments in Brazil, while coffee stood out as more cost-effective, followed by bean, peanut and soybean, respectively. Following the NPV and RBC trends, IRRs were always well above than the minimal attractiveness rate of $7 \%$ recommended by Mugabi \& Discroll ${ }^{13}$ and Marquezan ${ }^{14}$ as the minimum acceptable return percentage that grain drying systems must earn in order to be economic feasible. Even for corn, rice and wheat, which presented lower IRRs, high-temperature grain drying appears as a low risk and profitable investment for all simulated scenarios. Greater PP values indicate that the capital invested in the high-temperature drying will be committed for several years, resulting in riskiest projects. However, the PPs obtained in this study corresponded to less than one fifth of the project lifetime, confirming the high-temperature grain drying as a worthwhile and low risk investment in Brazil.

Selling prices of grain strongly affected the economic results since high value products, such as coffee, bean and peanut, are capable of generating greater revenues along the lifetime of the project, contributing to a faster recovery of the invested capital, as well as easily covering the process expenses. These results agreed with those presented in another works that evaluated high-temperature drying costs. ${ }^{13,15,19,35}$ Another important variable is the dried bulk volume, since for all grain types, large dryers were more profitable even presenting greater initial investments. According to Costa et al. ${ }^{19}$ this behavior can be justified by the fixed costs associated with the drying process, which are independent of the dryer capacity and drying cycles. These include insurance, taxes, fees and inflation rate.

When considering high-temperature dryers the required initial investment is the variable of major impact on the system implementation. Comparing this initial capital with that required by low-temperature drying systems it is observed an average difference of $67 \%{ }^{20,24,25,36}$ On the other hand, this high initial investment is partially offset by the reduced process costs, such as electrical energy and labor, due to the short drying time observed in this kind of system.

Furnace fuel did not considerably influence the economic indices when evaluated separately. Although a large amount of wood was required when simulating the high-temperature drying, this fuel has a low cost in Brazil, what explains the slight economic difference between scenarios where only the furnace fuel varied. The low costs of wood and grain residues as furnace fuels were also observed by Valente et al., ${ }^{12}$ Lim et al. ${ }^{37}$ However, costs of both wood and grain residues tend to increase depending on different freight values, as well as labor required for prepare these fuels to be used into the furnace. In the case of wood, the distance between the dryer and the fuel supplier tends to affect the freight cost directly, as well as the region where the wood is acquired.

Despite the similar economic results of wood and grain residues in relation to high-temperature drying, it is important to emphasize the benefits of using biomass as alternative fuel for this process. Wood combustion is generally incomplete and did not liberate all available chemical energy, also generating toxic gases, such as the polycyclic aromatic hydrocarbons (PAHs). These organic compounds are formed during the pyrolysis of some organic materials and are considered environmental pollutants, since they are non-biodegradable, and are also known to have carcinogenic potential. ${ }^{8}$

On the other hand, grain residues present greater combustion efficiency, can be found in large amounts and are easily available for immediate use. These fuels also present, in many situations, low calorific values greater than those of wood and thus possess high energy contents. Furthermore, biomass can be converted into heat with very low carbon emissions, contributing to more sustainable agricultural practices. ${ }^{10,37}$ Another advantage of using grain residues as furnace fuel during grain drying is that this practice does not detrimentally affect traditional agricultural management, such as tillage, heating and animal feed. According to Wang and Mendelsohn, ${ }^{38} 15 \%$ of crop residues in field is sufficient for providing adequate soil fertilization and protection, while $25 \%$ is generally used for animal feed and industrial raw materials. Simulations performed in this study showed that around 1.9, 2.8, 3.3, 3.5, 3.5, 3.8 and $8.75 \%$ of the biomass from plantations was required as furnace fuel for high-temperature drying of coffee, bean, soybean, wheat, rice, corn and peanut, respectively. In all these cases residue availability was guaranteed for other agricultural practices.

\section{Conclusion}

All simulated scenarios were economic feasible and considered as low-risk investments since operating at least five drying cycles per year. High-temperature drying of large volumes (from $227.1 \mathrm{~m}^{3}$ ) of coffee and bean stood out as more profitable, resulting in greater NPV, $\mathrm{BCR}$ and IRR values. The smallest returns were observed when drying small and middle volumes of corn and rice. The factors that main affected the profitability of high-temperature drying were the grain type, dryer size, labor, social taxes and initial investment. Generally, high cost grains and large dryers were responsible for greater revenues along the lifetime of the project. The furnace fuel did not interfere considerably in the evaluated economic indices. However, the use of grain residues as drying fuel was recommended due to their environmental benefits. The proposed methodology requires both technical and economic knowledge about the high-temperature grain drying, including several data about the dryer and grain, as well as economic data, such as inflation rate, tax values and prices. But, it can be applied to other grains, country market conditions, furnace fuels, and drying capacities as well.

\section{Acknowledgments}

The authors thank the Coordination for the Improvement of Higher Education Personnel (CAPES) for the the Master degree grants.

\section{Conflicts of interest}

There were no conflicts of interest.

\section{References}

1. Jokiniemi HT, Ahokas JM. Drying process optimization in a mixed-flow batch grain dryer. Biosyst Eng. 2014;121:209-220.

2. Mansor H, Mohd Noor SB, Raja Ahmad RK, et al. Intelligent control of grain drying process using fuzzy logic controller. J Food Agric Environ. 2010;8(2):145-149. 
3. Norton GJ, Shafaei M, Travis AJ, et al. Impact of alternate wetting and drying on rice physiology, grain production, and grain quality. Field Crops Res. 207;205:1-13.

4. Coradi PC, Fernandes CHP, Helmish JC. Adjustment of mathematica models and quality of soybean grains in the drying with high temperatures. Rev Bra Eng Agr Amb. 2016;20(4):385-392.

5. Odjo S, Bera F, Beckers Y, et al. Influence of variety, harvesting date and drying temperature on the composition and the in vitro digestibility of corn grain. J Cereal Sci. 2018;79:218-225.

6. Cheevitsopon E, Noomhorm A. Effects of parboiling and fluidized bed drying on the physicochemical properties of germinated brown rice. Int J Food Sci Tech. 2018;46(12):2498-2504.

7. Weigler F, Scaar H, Franke G, et al. Optimization of mixed flow dryers to increase energy efficiency. Dry Technol. 2017;35(8):985-993.

8. Lima RF, Dionello RG, Peralba MCR, et al. PAHs in corn grains submitted to drying with firewood. Food Chem. 2017;215:165-170.

9. Cardoen D, Joshi P, Diels L, et al. Agriculture biomass in India: Part 1. Estimation and characterization. Resour Conserv Recycl. 2015;102:3948

10. Bilandzija, N Voca, N Jelcic B, et al. Evaluation of Croatian agricultural solid biomass energy potential. Renew Sust Energ Rev. 2018;93:225230 .

11. Singh J. Identifying an economic power production system based on agricultural straw on regional basis in India. Renew Sust Energ Rev. 2016;60:1140-1155.

12. Valente DSM, Queiroz DM, Correa PC, et al. A decision support system for cost determination in grain storage facility operations. J Braz Ass Agr Eng. 2011;31(4):735-744.

13. Mugabi R, Driscoll R. Study of Maize Drying in Uganda Using an in-Store Dryer Weather Data Simulation Software. Intl J Food Proc Technol. 2016;3(1):18-26.

14. Marquezan LHF. Investment analysis. Rev Eletr Contab. 2006;3(1):110

15. Filho EF, Gottarde R, Dionello RG. Costs of intermittent drying of corn kernels subjected to three drying air temperatures $\left(60,70\right.$ and $80{ }^{\circ} \mathrm{C}$ ). Research Agropec Gau. 2010;16:17-21.

16. Lawrence J, Atungulu GG, Siebenmorgen TJ. Modeling in-bin rice drying using natural air and controlled air drying strategies. ASABE. 2015;58(4):1103-1111.

17. Oliveira V, Santos RF, Rosa HA, et al. Economic and financial analysis of the implementation of a water-tube boiler in the process of grain drying using a column dryer. Afr J Agric Res. 2016;11(2):100-104.
18. Taner T. Optimisation processes of energy efficiency for a drying plant: A case of study for Turkey. Appl Therm Eng. 2015;80(5):247-260.

19. Costa DR, Lacerda Filho AF, Sousa J, et al. Cost analysis of corn drying systems in mechanical dryers. Rev Eng Agr. 2010;18(1):62-76.

20. Jasper SP, Biaggioni MAM, Ribeiro JP. Economic feasibility of acquiring a dryer-silo for small production areas. Eng Agr. 2006;26(3):795-803.

21. Lopes DC, Steidle Neto AJ, Mendes AA, et al. Economic feasibility of biodiesel production from Macauba in Brazil. Energy Econ. 2013;40:819-824.

22. Lopes DC, Steidle Neto AJ. Preliminary Economic Study of Biodiesel Production from Pequi in Brazil. Open Access J Sci. 2017;1(5):139-143.

23. CASP. Equipment for high-temperature grain drying. 2019.

24. Comil. Silos and Dryers. 2019

25. Kepler Weber. Postharvest equipment. 2019.

26. Conab. National Food Supply Company. 2019.

27. Lopes RP, Sobrinho JC, Silva JS, et al. Energy sources for drying coffee. Brazil: Technical Bulletim 03. Vicosa; 2001.

28. EPE. Energy Research Company-Energetic Inventory of Rural Residues. Brazil: Technical Note DEA 15/14, Rio de Janeiro; 2015.

29. Fasina OO. Physical properties of peanut hull pellets. Bioresour Technol. 2008;99(5):1259-1266.

30. Bank of Brazil. Tables of values. 2019.

31. CEMIG. Minas Gerais Power Company. 2019

32. Cemar. Maranhão Power Company. 2019.

33. Eletropaulo. São Paulo Power Company. 2019

34. IEA. Agricultural Economics Institute. 2019.

35. Ribeiro JP, Biaggioni MAM. Economic-energy assessment of combined corn drying. Energ Agr. 2006;21:36-54.

36. Polidryer. Design of drying systems. 2018.

37. Lim JS, Manan ZA, Alwi SRW, et al. A review on utilization of biomass from rice industry as a source of renewable energy. Renew Sust Energ Rev. 2012;16:3084-3094.

38. Wang X, Mendeslsohn R. An economic analysis of using crop residues for energy in China. Environ Dev Econ. 2003;8(3):467-480. 